\title{
An Evaluation Of The Implementation Of Fair Value Accounting: Impact On Financial Reporting
}

Karen T. Cascini, Sacred Heart University, USA

Alan DelFavero, Sacred Heart University, USA

\begin{abstract}
The accounting industry is in a state of continuous change. In the United States, the historical cost principle has traditionally been the foundation of accounting. Until recently, assets and liabilities have been required to be recorded at their acquisition prices, with the exception of designated financial assets and financial liabilities. However, the Financial Accounting Standards Board (FASB) has now created accounting standards that are distant from the cost principle. Statement of Financial Accounting Standards No. 157: Fair Value Measurements, issued in September 2006 (FAS157, now codified as ASC 820) and Statement of Financial Accounting Standards No. 159: The Fair Value Option for Financial Assets and Financial Liabilities, created in February 2007 (FAS159, now ASC 825-10-25), significantly increases the viability of fair value accounting. The purpose of this paper is to illustrate the benefits and pitfalls of fair value and the corresponding affects on various stakeholders.
\end{abstract}

Keywords: fair-value accounting; fair-value option; mark-to-market; financial crisis; subprime; investor risk; equities; collateralized debt obligations; liquidity; earnings management; earnings restatements; convergence

\section{FAIR VALUE ACCOUNTING: A HISTORICAL PERSPECTIVE}

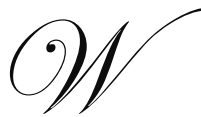

hile the concept of fair value accounting (FVA) may be considered new by the majority of the public, the principle has existed for decades. As early as the 1930s, FVA (also referred to as mark-tomarket accounting) became an integral part of financial accounting. However, in 1938, former

President Franklin Delano Roosevelt abolished the accounting measurement technique as it was believed that market-to-market accounting contributed to the severity of the Depression, thus causing financial institutions to fail (Stein \& Wesbury, Feb. 24. 2009). At that time, FVA was not created or enforced by any formal standard-setting body, such as the FASB. However, the first major step towards enforcing FVA, in present-day financial accounting, occurred in December 1975, as the FASB issued Statement of Financial Accounting Standard No. 12 (FAS12): Accounting for Certain Marketable Securities. At this time, the FASB allowed firms, for the first time, to report unrealized losses and unrealized gains on marketable securities in income. However, one stipulation was that firms could only report unrealized gains in income for financial instruments where previous write-downs occurred (McCarthy\& Schneider, July 2007, p.28).

For example, if a marketable security was purchased at the beginning of Period One, and then the financial instrument subsequently decreased in value by $10 \%$ through the end of the first period, the unrealized loss would be recorded in income. With regard to unrealized gains, if the $10 \%$ loss was partially or fully recovered in a future period, those unrealized gains could be recorded in income. Nonetheless, if the initial change in the asset's value was an increase of $10 \%$ in Period One, that unrealized gain could not be recorded in income.

The next major financial accounting standard that fully focused on fair value (FV) was FAS107: Disclosures about Fair Value of Financial Instruments, (now codified as ASC 825) issued in December 1991. FAS107/ASC825 stretched the existing FVA regulations of the time by "requiring all entities to disclose the fair values of financial 
instruments" (FASB, SFAS107, 1991, p. 4). FAS107 became effective in December 1992 for organizations with total assets over \$150 million and for all corporations as of December 1995 (FASB, SFAS107, 1991, p. 4).

Subsequently, in October 1994, FASB issued FAS119: Disclosure about Derivative Financial Instruments and Fair Value of Financial Instruments. FAS119 amended FAS107 by requiring companies to disclose information pertaining to derivative financial instruments, including "futures, forward, swap, and option contracts, and other financial instruments with similar characteristics" (FASB, SFAS119, 1994, p. 5). Derivative securities include futures contracts, currency swaps, forward contracts, etc, and obtain their value from an underlying security. The standard was mainly issued with the purpose of drawing a clear difference between accounting for investments held for the purpose of a trade, as opposed to those "held or issued for other purposes" (FASB, SFAS119, 1994, p. 4). Ultimately, FAS119 required that gains and losses resulting from these derivatives flow through the income statement regardless of the impact on net income. Nonetheless, the accounting standards that are primarily considered to be the "FVA standards" today are FAS157: Fair Value Measurements and FAS159: The Fair Value Option for Financial Assets and Financial Liabilities, which will be addressed below.

\section{FAIR VALUE ACCOUNTING EXPANSION}

FAS157 (referred to as ASC 820 from this point forward): Fair Value Measurements "defines fair value (FV), establishes a framework for measuring FV, and expands disclosures about FV measurements" (FASB, FAS157, 2006, p. 1). Prior to ASC820, a specific standard defining FV and a framework indicating its effective application did not exist. FV is described as the price which an asset or a liability could be sold or exchanged for in a theoretical transaction as of the balance sheet date. This is commonly referred to as the exit price. Assets and liabilities subject to FVA may be rendered as either stand-alone or group in nature. Stand-alone assets refer to financial instruments or operating assets; group assets include a business or reporting unit (Ibid, p. 2). In terms of valuation, the market approach, income approach, and/or the cost approaches are used when determining FVs for a financial asset or financial liability. The market approach uses available information relating to similar or identical assets or liabilities. The income approach, on the other hand, uses a discount rate to reduce the projected future value from cash flows or earnings from the asset or liability to its present value. Conversely, the cost approach values an asset at replacement cost, which represents the cost of replacing an asset in a hypothetical sale (Ibid, pgs.7-8). ASC 820 became effective for financial statements issued as of November 15, 2007. However, adoption of the standard by entities prior to this date was highly supported by the FASB (Hughes, 2007, p.1).

Under ASC 820, the FASB designates three different categories of valuation criteria for assets and liabilities, which are classified as level one, two, or three inputs. Omar Esquivel and Sylvia Gornik-Tomaszewski, authors of "FV Measurements in Impairment Testing: How SFAS No. 157 Increases Consistency and Comparability," published in the Review of Business in 2007, present a valuable hierarchy chart for these three levels of input-classifications, which is displayed in Exhibit 1.

Essentially, a level one input consists of obtainable quoted prices for identical assets/liabilities in the marketplace. FASB recognizes that level one is the most reliable pricing method due to constant market activity (FASB, FAS157, 2006, p. 10). Level two inputs are implemented when assets and liabilities do not have identical counterparts or belong to a market with light volume. Thus, prices or other forms of market information (such as interest rates) for similar assets and liabilities are used (Ibid, p. 10). Last, level three inputs are the most difficult to derive since market quotes normally do not exist. In this case, a company may need to value an asset or liability based on its own internal assumptions or consult with a valuation specialist (Ibid, pgs. 11-12).

Based on the assertions of Esquivel and Gornik-Tomaszewski, the above inputs may be categorized into observable and unobservable. Observable inputs are those which are acquired from market data outside the entity. Conversely, unobservable inputs are those which cannot be readily located, and thus, a company must formulate its own estimates using any information available (Esquivel \& Gornik-Tomaszewski, p. 20) 


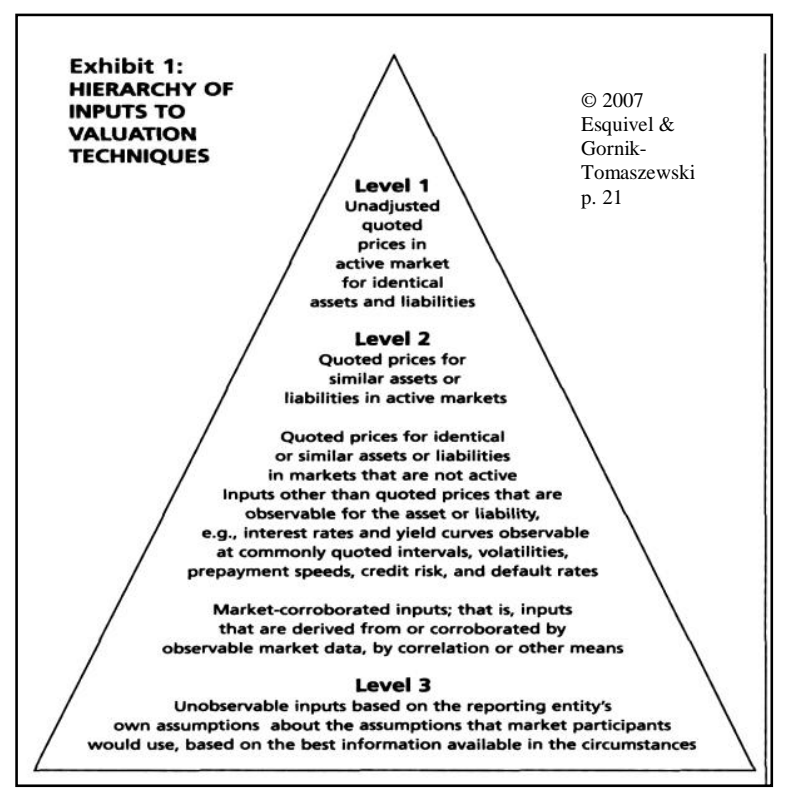

On the other hand, FAS159: The Fair Value Option for Financial Assets and Financial Liabilities (now referred to as ASC 825-10-25), was created in February 2007, to establish "presentation and disclosure requirements designed to facilitate comparisons between entities that choose different measurement attributes for similar types of assets and liabilities" (FASB, FAS159, p. 1). Essentially, companies can elect to apply FVA to permitted financial assets and liabilities that have not previously been measured at their respective current values (Ibid, p. 1). The accounting standard can be "used on an instrument by instrument basis." In essence, an enterprise can choose to use the accounting method for one financial asset or financial liability and decide to continue to apply the cost principle to another financial instrument (Ratcliffe, Dec. 2007, p.61). Once an entity elects to adopt FV for a financial asset or financial liability, it cannot change the valuation method back to historical cost (S. Johnson, May 1, 2008). However, under ASC 825-10-25, the estimated increase (decrease) in value is recognized as an unrealized gain (loss) on the income statement during each accounting period (McCarthy \& Schneider, 2007, p.32).

The FV Option was unique in its premise as it provided an opportunity to firms at the initial adoption date. The FASB required that an entity choosing to early adopt this standard must implement ASC820 in tandem (FASB, FAS159, p.14). Though the principle suggests that all unrealized gains or losses must flow through to the income statement, this was not true for preexisting financial assets at the time of initial adoption. At the first application, any cumulative unrealized gain/loss on a financial asset/liability could be posted to the period's retained earnings starting balance. In reality, the original write-ups/downs on these financial instruments could impact the balance sheet and capital ratios, but circumvent the income statement altogether (Henry, Jun. 2009, p.182). However, in future periods, unrealized gains/losses on the selected instruments flow through to the income statement. Subsequent to the date of execution, the FV Option can also be applied to newly purchased/issued financial assets/liabilities on the date of acquisition/incurrence (FASB, FAS159, p. 4). However, from the beginning, unrealized gains/losses will be considered an income statement component and will affect earnings accordingly.

\section{THE FASB'S PURPOSE}

What was the FASB attempting to accomplish by issuing new FVA standards? There are several answers to this question. First, there is the issue of earnings volatility and management. In the past, inconsistencies have arisen as GAAP required some assets and liabilities to be reported using FVs, but not others. Consequently, there have been fluctuations in earnings as a result of the different reporting methods. Thus, a main goal of ASC 825-1025 is to help companies, especially those in the financial services sector, to reduce intense earnings gyrations. Prior to the FV Option, securities held as investments that were classified as held-to-maturity or available-for-sale would only translate into gains or losses in income upon sale or impairment. The selling price may be radically different 
from the historical price, giving the investor a false reading on the firms' profitability, or lack thereof, during a particular accounting period. However, if the FV Option was elected for those instruments, the corresponding gains and losses would flow to the income statement each period. At the time of sale or extinguishment, the asset or liability's gain or loss would not have as great of an impact on earnings as in the pre-FV Option period.

Additionally, Multinational Corporations (MNCs) argue that uniformity among financial reporting standards is necessary. Large international conglomerates have been required to prepare their financial statements under International Financial Reporting Standards (IFRS) and U.S. GAAP, assuming that they are publicly listed in the United States. (This dual requirement was eliminated in 2009 as the SEC now accepts IFRS for foreign entities that have their stocks also listed on a U.S. stock exchange as an American Depository Receipt).

Accordingly, on September 18, 2002, the FASB and the International Accounting Standards Board (IASB) entered an accord called "The Norwalk Agreement," (also known as 'The Convergence Project') which aimed at "(a) making existing financial reporting standards fully compatible as soon as practicable, and (b) to coordinate their [FASB] future work programs to insure that once uniformity is achieved, compatibility is maintained" (FASB, Memorandum of Understanding, p.1). The FASB's original goal was to converge most financial accounting standards by January 2005. Yet, as noted, the first major standard that modeled an international rule was ASC820, which partly replicated International Accounting Standard No. 39 (IAS39): Financial Instruments: Recognition and Measurement. IAS39's definition of FVA is slightly different from ASC820 \& ASC 825-10-25. According to IAS39, "fair value is the amount for which an asset could be exchanged between knowledgeable, willing parties in an arm's length transaction" (Imeson, Nov. 2008). IAS39 categorizes financial assets into four specific groupings, which are listed as follows: "(1) those financial assets held for trading purposes; (2) those available for sale; (3) those held to maturity; (4) and loans and receivables" (Ibid). Though the enhanced similarity among accounting standards appears to be an objective, the primary intention of standard-setters is to universally apply IFRS worldwide. A full convergence was scheduled for 2011, (S. Johnson, Feb. 8, 2008) but now appears to be delayed until about 2015 (Gramling \& Hermanson, Nov/Dec 2009, pg. 36).

At face value, these standards sound beneficial to the field of accounting. Both the FASB and the IASB reinforced the notion that the sole use of historical cost was "out-of date" and "lacked transparency," and a movement toward FV-based accounting was essential (Leone, May 30, 2008). However, there has been a significant backlash from corporate executives over the past few years. Yet, positive comments have been present as well. Cases of entities wrestling with the FV concept, in addition to the corresponding commentary, will be presented throughout this paper.

\section{THE PRELIMINARY PERIOD}

As the FASB encourages adoption of newly issued accounting standards prior to their effective dates, numerous companies implemented both ASC820 and ASC 825-10-25 during early-2007. According to an August 2008 Deloitte study, multiple firms in the financial services sector adopted early, including Citigroup, Bank of America, Goldman Sachs, JPMorgan Chase, Merrill Lynch, Morgan Stanley, and KKR Financial (Deloitte, August 2008, p. 12). Nonetheless, while multiple companies originally believed that early implementation would be beneficial, some firms subsequently regretted their decision.

Based on the findings of Dr. Elaine Henry, Assistant Accounting Professor at the University of Miami and author of "Early Adoption of SFAS No. 159: Lessons from Games (Almost) Played," in the June 2009 edition of Accounting Horizons, out of a total of 427 banks, "35 disclosed the early adoption of [ASC 825-10-25], among which 11 [commercial banks] rescinded or revised the early adoption decision" (Henry, Jun. 2009, p.186). Dr. Henry asserts that all eleven firms debited (decreased) retained earnings due to significant unrealized losses that had previously existed, and as a result, experienced enhanced profitability by the end of the first quarter of the application (Henry, June 2009, p. 191). A fundamental issue however, is that most of these firms that did an aboutface and "characterized early adoption as an opportunity to enhance their securities and thus benefit future...income" (Henry, June 2009, p. 192). 
Professor Henry presents examples of firms that later terminated application. Henry cited Seacoast National Bank of Florida's management, who stated, "[early adoption of FAS159] enables us to better align the financial results of those [financial instruments] with their economic value" (Henry, Jun. 2009, p. 192). The adoption occurred as of January 1, 2007, and translated into a $\$ 3.7$ million cumulative effect adjustment to the opening balance of retained earnings. While the company initially claimed that the early adoption facilitated an increase in transparency, management later decided that the decision reduced clarity. As a result, Seacoast restated financial statements, thus shifting the $\$ 3.7$ million cumulative effect adjustment to a charge for their first quarter of 2007 in order to achieve better transparency (Ratcliffe, Dec. 2007, p.61).

Other examples included Cadence Financial Corporation, who adopted the FV Option as of January 2007. Cadence applied the FV Option to eligible securities, debited retained earnings for a $\$ 3.6$ billion unrealized loss, and subsequently, included a $\$ 726,000$ gain in the first quarter of 2007 income. This gain was attributable to the sale of the devalued securities shortly after the implementation of the FV Option. Essentially, Cadence wrote down the securities to their present values at the time, hid those losses in retained earnings, and then reported the corresponding recovery in income. Nonetheless, the firm reversed its decision to early adopt ASC825-10-25 and consequently, restated earnings from an originally reported $\$ 3.7$ million to a mere $\$ 103,000$, as the "unrealized loss" was realized in actuality (Henry, June 2009, p. 185).

Henry indicated that the "rescinding" parties primarily abandoned their previous decision to adopt as the intended use of the standard did not comply with its "intent." Additionally, nearly all of the institutions' disclosures suggested that the FASB's guidance, at the time, was highly limited and it was the "informal sources of guidance [that] provided more specific direction [than]....the standard itself" (Henry, 2009, p.197). A major argument was that as the early adoption provided the opportunity for firms to "hide" cumulative unrealized losses in retained earnings, certain aspects of financial reporting may now appear to be unethical.

\section{ARGUMENTS AGAINST FV}

While reliability of financial reporting may improve, one of the major negative arguments is that comparability may diminish due to the continuous adjusting and impairing of asset and liability values. For instance, one company may opt to use FV when determining the worth of a financial instrument, while another may choose to continue to use cost (McCarthy \& Schneider, July 2007, p.34). Presented below are numerous examples of entities that have faced trouble as a result of implementation. A graphical representation of institutions adversely impacted is shown in Exhibit 2.

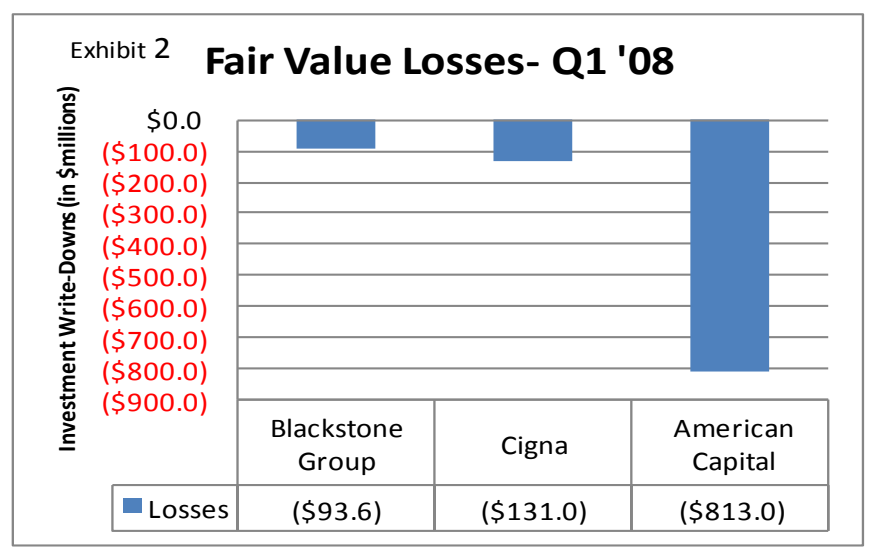

Health insurance provider, Cigna, who implemented the valuation procedures set forth by ASC 820 on January 1, 2008, blamed an 80\% decline in their first quarter 2008 earnings on the rule. According to the healthcare giant, a significant portion of the loss in earnings was due to a post-tax \$131 million (\$202 million pre-tax) "hit in its guaranteed minimum income benefit (GMIB) business" (S. Johnson, May 1, 2008). Though Cigna terminated 
operations of its GMIB reinsurance business in 2000, residual assets and liabilities were still on its books, and consequently, were revalued using the hierarchy set forth in ASC 820. In the opinion of the company's former-CFO, Michael Bell, in a 2008 interview, ASC820 is a "very, very conservative accounting standard" (Ibid). (As of May 2009, Michael Bell resigned as CFO and was succeeded by Ms. Ann Marie Hagan) (Cigna, 2010).

Going forward, the Company indicated that there will be earnings volatility from the FV measurements for the foreseeable future (Cigna 2008 Annual Report, 2009, p.63). As of the 2008 annual report, Cigna specified that only the GMIB business would be affected by changes in FV measurements. Nonetheless, the insurer indicated there wasn't any active market for these financial instruments, and consequently, hypothetical exit prices were supplemented for actual market quotes (Cigna 2008 Annual Report, 2009, p.87). Financial statement preparers at Cigna stated, "For many of these assumptions there is limited or no market observable data so determining an exit price requires the Company to exercise significant judgment to make critical accounting estimates" (Ibid, p.87). Was the \$202 million pre-tax loss from the write-down under FV "real," as the losses were based on theoretical prices?

Next, American Capital Strategies, a private equity firm, "reported a loss of $\$ 813$ million for the first quarter of 2008" (Taub, May 8, 2008). The company asserts that the book values of the assets were depreciated by approximately $\$ 656$ million. However, the establishment projected that many of these assets would actually increase in value, and the rule would have a positive influence on earnings in subsequent reporting periods. The president \& CEO, Malon Wilikus, indicated that most of the depreciated "third tier" securities were scheduled to be held until maturity, and at that time, the assets will likely climb in value (Ibid). In this case, earnings volatility appears to have been amplified. According to the American Capital 2008 annual report, the firm primarily invests in assets deemed as level three. Therefore, the corporation indicated that the artificial market values developed under the requirements of ASC 820 "are materially lower than the values [they] anticipate realizing on settlement or maturity" (American Capital 2008 Annual Report, 2009, p.27).

As a direct result of the adoption of ASC 820, there was a corresponding $\$ 447$ million decrease in American Capital's investment assets during 2008, principally in its private finance portfolio for debt and redeemable preferred securities. The company adopted a market yield approach in a theoretical secondary market (American Capital 2008 Annual Report, 2009, p.57), which included "third-party broker quotes,...synthetic credit ratings, current market yield and interest rate spreads of similar securities as of the measurement date" (Ibid, p.87). Essentially, American Capital applies valuation techniques that fall between those traditionally used to value level two and level three financial instruments. However, by the end of the third quarter of 2009, the private finance portfolio's cumulative FV losses were cut by $\$ 112$ million to $\$ 335$ million, mainly as a result of improving financial market conditions (Ibid, p.75).

Blackstone Group, another private equity firm, which invests in other companies, reported a loss of $\$ 93.6$ million during the first quarter of 2008. While FV is not considered to be the sole cause of this negative result, according to the company's president and COO, Tony James, "FAS157 [ASC 820] aggravated and exaggerated the problem" (Trincal, 2008). The corporate president alluded to the fact that earnings have been significantly diminished due to the revaluing of an investment at its current price. For instance, James stated that even though an asset may be purchased and the firm expects a $25 \%$ return over a five year period, "you have to mark it as if it were selling today...... but this mark is completely artificial...[and] it's silly" (Ibid).

Furthermore, in the Blackstone Group's 2008 annual report, the company presents an example of how ASC 820 could present an inaccurate reflection of market value, suggesting that "the markdowns" generated during 2008 "were disappointing, but did not necessarily reflect permanent loss of value" (Blackstone Group, 2008 Annual Report, 2009, p.14). The report further proposed an example of how market values would be impacted for those acquired just prior to the 2002-03 market debacle (which was the last significant bear market for equities) if ASC 820 were in place at that time. The results suggested that those instruments would have declined in value by approximately $70 \%$ by the time the market bottomed in early-2003. Yet, those assets were eventually sold for or later valued at eight times the implied value at the 2003-low. The company's concluded by stating, "As our investors, you should understand that markdowns under ASC 820 do not necessarily reflect the ultimate investment result" (Ibid, p.14). 
Based on the claims of CFO Magazine's Tim Reason, author of "Why CFOs Hate Fair Value," "CFOs generally hate FV because it makes their companies' bottom line numbers move up and down in ways they can't control" (Reason, May 14, 2008). For instance, Reason declared that FVA generates a great deal of stresses for CFOs, since they are forced to alert investors that a deterioration in earnings is not due to the company's true performance; corporate treasurers will need to be appropriately educated; and deliberations with auditing firms regarding appropriate valuation techniques will need to occur continuously (Ibid).

In addition, the resulting impacts of FV on liabilities appear to be counterintuitive. For instance, if a company encounters significant financial difficulty, any outstanding debt (bond and note issuances) should "reflect the risk that the company won't pay them back" (Katz \& Reason, July 9, 2008). Hence, the bond/note may be settled well before maturity at a price far below the liabilities' par value(s). As a result, the present value of these liabilities decrease as default risk increases, thus, providing a potential increase in earnings. According to Credit Suisse, during the first fiscal quarter of 2008, twenty-five companies with rather large amounts of debt in risk of default generated gains to income of between $\$ 11$ million and $\$ 3.6$ billion (Ibid). James Tisch, president and CEO of Loews Corporation and also a panel member, declared "It [provision 15 of ASC 820] is going to destroy the notion of the income statement and make it unusable for investors who just want to see how a company did for a quarter" (Ibid).

Correspondingly, Thomas Linsmeier, a FASB member, and Dr. Kathy Petroni, a Michigan State University accounting professor, indicated that these "gains" related to an increase in credit risk was, in the long-term, a sign of a larger decrease in asset values since, and in most cases, a decline in assets will be larger than the gains related to the increased default risk. Linsmeier stated, "The gain on the liability side should not be treated as a gain, but as a signal of losses on the asset side" (Katz and Reason, July 9, 2008). Although FV, in this respect, may not be viewed upon as negative from a corporate point of view, it can cause vast confusion among investors.

\section{FV'S ALLEGED ROLE IN THE SUBPRIME CRISIS}

As ASC 820 and ASC 825-10-25 were implemented in the midst of the 2007-09 subprime crisis, difficulties associated with pricing level three securities has been argued by some to have caused the economic downturn. A few months before the crisis began to accelerate; CFO Magazine's Sarah Johnson authored "Illiquid Markets Rock Fair-Value Accounting." The piece suggested that banking executives "claimed the use of FV for assessing financial instruments has led to volatile income statements, and the growing number of billion-dollar-plus write-downs for financial services firms" (S. Johnson, April 29, 2008). According to CNBC, by mid-September 2008 , the financial services industry endured $\$ 500$ billion of mark-to-market write-downs on a global scale (CNBC.com, September 2008).

\section{The Mortgage-Backed-Security}

Nonetheless, a major culprit of the massive write-downs endured by the financial services sector was a result of significant exposure to mortgage-backed-securities. The SEC defines mortgage-backed securities as "debt obligations that represent claims to the cash flows from pools of mortgage loans, most commonly on residential property..... [typically] the most basic types are pass-through participation certificates, which entitles the holder a pro-rata share of all principal and interest payments made on the pool of loan assets" (SEC, 2007).

Sir David Tweedie, chairman of the International Accounting Standards Board (IASB), acknowledged that the implementation of FVA forced financial firms to revalue mortgage backed securities at their respective current values, thus forcing the "true downsides of a company's investment" to appear on financial statements (S. Johnson, March 19, 2008).

In addition, according to a May 2008 CPA Journal article, entitled "Mortgage Backed Securities and FairValue Accounting," authored by Tim Krumwiede, Ryan Scadding, and Craig Stevens, a significant portion of mortgage-backed-securities were issued by private investment banks and did not offer the low risk and protection as those supported by the U.S. Government. Effectively, mortgage-backed securities issued by private investment banks did not have an assurance of full repayment. The article cites statistics provided by The Office of Federal 
Housing Enterprise Oversight (OFHEO), which indicated that by 2006, approximately $56 \%$ of all mortgage-backedsecurities were issued by private entities as opposed to $20 \%$ during 2001. It is quite obvious that these private mortgage-derived securities would carry greater credit risk as opposed to their government-sponsored counterparts (Krumwiede, Scadding, and Stevens, May 2008, pgs. 30-32).

Furthermore, the piece suggests that a vast number of these derivatives were "collateralized by subprime mortgage loans" (Krumwiede, Scadding, and Stevens, May 2008, p.32). Although the aforementioned article was published prior to the height of the credit debacle in the late-summer/fall of 2008, the authors suggested that "fairvalue measurements, based on the use of unobservable inputs (Level 3), require the use of significant professional judgment" (Ibid, p.36). They further believed that significantly declining market values would put CPAs' professional judgment "to the test" as diminishing trading volume and sliding home values were bound to create significant difficulties for a clear measurement of "FV." Chiefly, for those derivatives which the FV Option (ASC 825-10-25) was applied, any perceived losses would be recognized both on the balance sheet and in income. On the other hand, if ASC 825-10-25 was not adopted, and if it was deemed that an asset's decline in value is permanent, under the provisions of FAS115, an impairment loss must be incorporated into earnings (Ibid, p.33). Effectively, the above authors appear to disagree that the "true" value of a mortgage-backed-security is revealed when mark-tomarket accounting is used.

Subsequently, in the fall of 2008, the financial markets crashed and the U.S. economy approached the brink of collapse. The shockwaves from this debacle caused bankruptcies among traditional banks, brokerage firms, and the insurance industry. During 2008 and 2009, there were 26 and 140 "traditional" bank failure cases that were closed by the Federal Depository Insurance Corporation, respectively (FDIC, 2010). A "traditional" bank is primarily a financial institution that provides customers with deposit and checking accounts and distributes funds via personal and business loans. However, the impact on global investment and insurance conglomerates, along with the entire financial sector, is the primary focus.

\section{Examples of Impacted Financial Service Firms}

During the downfall of the U.S. financial services sector, mammoth companies, in terms of both market capitalization and international exposure, either plummeted into the bankruptcy or came perilously close to nearing collapse. A summary chart of the major financial failures is displayed in Exhibit 3. Firstly, with regard to American International Group (AIG), "FVA has been cited as a contributing factor in its collapse" (C. Johnson, Sep. 2008, p. D1). In March 2008, AIG "urged regulators to change controversial accounting rules [ASC820 and ASC 825-10-25] on asset valuations to stem the tide of write-downs" (Guerrera \& Hughes, Mar. 2008, p.15). In response, AIG proposed their own plan which indicated that "companies and their auditors would estimate the maximum losses they were likely to incur over time and only recognize these in their profits. All other unrealized losses would be recorded on the balance sheet but would not affect profits" (Ibid p.15). Although feasible, the FASB never adopted this premise.

Based on the assertions of AIG, they contend that the "\$11 billion write-down that the company faced in the fourth quarter of 2007 would have been reduced to $\$ 3$ billion" if FASB allowed AIG's plan to be set in place (Guerrera \& Hughes, Mar. 2008, p.15). According to Mark Sullivan, AIG's CEO, "mark-to-market' rules forced companies to recognize losses even when they had no intention of selling the assets at the current prices, which created a vicious circle whereby companies recorded huge losses, lost investors' confidence, and were forced to raise funds at unfavorable prices" (Ibid p.15). In the second quarter of 2007, AIG reported record net income of over $\$ 4.2$ billion (AIG, Aug 2007). A shocking comparison to the record net loss of nearly $\$ 25$ billion in the third quarter of 2008 !

The massive losses resulted in AIG's liquidity crisis in September 2008, when the U.S. Government offered an $\$ 85$ billion bailout to the insurance giant. In addition, the liquidity problems did not end there as continuous downgrades from Moody's \& S\&P resulted in demands for additional funds from the U.S. Government. Thus, in December 2008, AIG took advantage of additional bailout funds by selling " $\$ 39.3$ billion of assets to the Federal Reserve Bank of New York" (Reuters, Dec. 2008). By March 2009, the U.S. government lent AIG \$173 billion (Lewis, March 2009). As of January 2010, however, the government aid appears to have taken effect as AIG 
has registered net income of $\$ 1.8$ billion and $\$ 1.2$ billion, in the second and third quarters of 2009, respectively. As a consequence, AIG's common stock price has re-bounded from a low of roughly $\$ 7$ per share in March 2009 to roughly $\$ 30$ per share by January 2010 (Yahoo Finance, Jan. 2010).

\begin{tabular}{|c|l|}
\hline \multicolumn{2}{|c|}{ Exhibit 3: Summary Timeline of Major Finanical Failures } \\
\hline & \multicolumn{1}{|c|}{ American International Group } \\
\hline Q4 2007- & Common stock price begins at roughly \$1300 (revers e-split adjusted) \\
\hline Q4 2007- & \$11 Billion in FV write-downs recorded \\
\hline Mar 2008- & Lobbyed for FVA rule changes \\
\hline Q3 2008- & Reported net loss of \$25 billion \\
\hline Fall 2008- & Upon near-collapse, the U.S. Government offered \$85 billion in aid \\
\hline Mar 2009- & U.S. Government dis tributed a cumulative \$185 billion in aid \\
\hline Mar 2009- & Common stock price declines to \$7 (reverse-split adjusted) \\
\hline Q2 2009- & Profit of \$1.8 billion recorded \\
\hline Q3 2009- & Profit of \$1.2 billion recorded \\
\hline Jan 2010- & Common stock price recovers to \$30 \\
\hline & \\
\hline & \\
\hline July 2008- & Sold a CDO portfolio, with a historical cost of \$30.6 billion for \$6.3 billion. \\
\hline Sept 2008- & Company nears collapse, and Bank of America acquires for \$50 billion \\
\hline & \\
\hline & \\
\hline Q1 2007- & \$554 million quarterly profit recorded \\
\hline Q4 2007- & \$854 million quarterly loss recorded as a result of mortgage-asset write-offs \\
\hline Mar 2008- & J.P. Morgan Chase Bank acquires for \$10 p/share as Bear files for bankruptcy protection \\
\hline
\end{tabular}

Other examples of financial firms enduring significant losses include Merrill Lynch. "In July 2008, Merrill sold a big structured-credit portfolio at 22\% of its historical cost" (Economist, Sep. 2008). The original value of these collateralized debt obligations (CDOs) was \$30.6 billion, which sold for a mere \$6.3 billion (C. Johnson, Sep. 2008, p. D1). According to an article authored by Katz, titled "Fair-Value Accounting's 'Atmosphere of Fear," while referencing a Standard \& Poor's conference, "the shift to fair-value accounting in the midst of the crisis spawned an 'atmosphere of fear' that lead to a 'lockdown' in the use of judgment in valuing securities" (Katz, May 19, 2008). Katz references Merrill Lynch's senior vice president and finance director, Christopher Hayward, who stated that numerous "firms in the financial-services industry lacked the models to create hypothetical markets when the real ones [markets] dried up" (Ibid). The lack of liquidity, combined with the inability to use models for theoretical markets can be argued to have contributed towards Merrill Lynch's near collapse in September 2008. Consequently, Bank of America acquired the financial-services giant for \$50 billion (Gasparino, 2008).

In relation to Bear Stearns, on June 21, 2007, "two hedge funds managed by the brokerage firm collapsed because of losses triggered by CDOs and other investments that involved subprime mortgage loans" (Van Denter, Oct/Nov 2008, p.6). As of January 2007, the CFO of Bear Stearns Asset Management speculated that there would be numerous challenges ahead when adopting ASC820. "First, there will be challenges in determining the most advantageous market if there is no principal market for assets, such as stock that is traded on multiple exchanges, and second, there will be difficulty in 'identifying source data for level three unobservable inputs" (Sinnett, Jan/Feb 2007 , p. 34). These worries proved to become reality when the investment firm neared bankruptcy on March 17 , 2008. Consequently, JPMorgan Chase Bank offered \$10 per share for the destitute investment bank.

According to Bear Stearns' 2008 unaudited annual report (published after the JPMorgan Chase acquisition),

“Substantially all of the company's assets and liabilities were carried at contracted amounts which approximate fair value. Assets that are recorded at contracted amounts approximating fair value consist largely of short-term secured receivables, including repurchase agreements, securities borrowed, customer receivables, and certain other 
receivables. The short term liabilities, carried at FV, consist of bank loans, repurchase agreements, securities loaned, and customer payables, which all approximate fair value" (Bear Stearns, May 2008).

Bear Stearns also disclosed "the unrealized gains and losses for Level 3 positions held as of the May 31, 2008, reporting date" (Bear Stearns, May 2008). Yet, a clearer earnings trend is shown in net income throughout 2007. During the year, net income decreased dramatically from $\$ 554$ million in the first quarter of 2007, to a loss of $\$ 854$ million in the fourth quarter of 2007, resulting predominantly from the large mortgage asset write-offs (Bear Stearns, May 2008).

\section{Corresponding Responses}

As the failures among the financial services firm began to mount, strong opposition to FV began to arise not only from financial executives, but also Congress. In September 2008, during deliberations regarding the economic emergency, Congress verified that the SEC had the premier authority to "suspend mark-to-market accounting," if it was deemed necessary (S. Johnson, October 6, 2008). Executives from across the financial services industry called for a complete ban of FVA due to the massive deterioration in earnings. As a consequence, Congress, during the discussions, called for the SEC to launch a study "into the effect FV has had on the marketplace" (Ibid).

On September 28, 2008, the aforementioned debate resulted in the birth of the Emergency Economic Stabilization Act of 2008. The Act, signed into law by Former-President George W. Bush on October 3, 2008, included the infamous $\$ 700$ billion bailout package for financial service firms (also referred to as the Troubled Asset Relief Program (TARP)), (A. Johnson, Oct. 2008) and contained 303 sections. Section 133 of the Act mandated that the SEC conduct an extensive investigation into FVA practices (House Committee of Financial Services, September 2008). The SEC concluded its report on FVA's impact on the financial institutions in December 2008.

The committee conducting this analysis scrutinized the potential ramifications on the balance sheets of fifty randomly selected financial services firms. The results showed that approximately $45 \%$ of total assets and $15 \%$ of total liabilities were subject to FV measurements. In addition, the report concluded that roughly $25 \%$ of the analyzed assets did affect the income recorded by financial institutions (SEC, 2008, p.4).

With regard to bank failures specifically, the committee's commentary concluded that "FVA did not appear to play a meaningful role" (SEC, 2008, p.4). The report argued that, although losses generated as a result of FV for some of these financial institutions were significant, the true cause for collapse "appeared to be the result of growing probable credit losses, concerns about asset quality, and.... eroding lender and investor confidence" (Ibid,p.4). In addition, the report referenced Stephen Ryan, Professor of Accounting and Peat Marwick Faculty Fellow, of NYU's Stern School of Business, who suggested that there "is no convincing empirical evidence' that FV caused the global economic crisis and that the crisis is primarily the result of bad operating, investing, financing decisions, poor risk management, and in some instances fraud" (Ibid, p. A-3).

In general, the SEC review committee determined that the FASB should provide further guidance, but asserted that FVA did not cause the financial crisis. Accordingly, the NYU professor suggested that the use of FVA for financial instruments, when properly disclosed, enhance usefulness to shareholders (SEC, 2008, p. A-3). Nonetheless, it appears that the general consensus coincided with the aforesaid comments as the committee argued that ASC 820 should have not been suspended at all, but merely improved. The Committee believed that an outright suspension of ASC 820 would negatively affect investor confidence in the system. Specifically, these recommendations focused on the FASB providing additional guidance related to level two and three assets/liabilities (SEC, 2008, pgs. 7-8).

Nonetheless, the FASB also issued its own expanded FV guidance. On October 10, 2008 (prior to the SEC's study), FASB Staff Position (FSP) FAS 157-3-Determining the FV of a Financial Asset When the Market for That Asset Is Not Active was released. FSP FAS 157-3 added an additional key example of how a firm should value level three financial assets when an active market is not present. Although this staff position did provide additional support, the investing public and financial institutions required further direction. Consequently, on April 9, 2009, 
the FASB issued FSP FAS 157-4- Determining FV When the Volume and Level of Activity for the Asset or Liability Have Significantly Decreased and Identifying Transactions That Are Not Orderly, which became effective on June 15, 2009 (Weiss, June 2009, p.1).

This staff position expanded and superseded the guidance offered in FSP FAS 157-3. According to Judith Weiss of Miller GAAP Update Service, FSP FAS 157-4 does not apply to financial instruments designated as level one. However, the update concentrates on clearly explaining to readers how to determine if an asset or liability belongs to an unruly market (Weiss, June 2009, p.2). Hence, as the core of the confusion in FV's application is attributed to hard-to-price-instruments that are classified as inactive, this additional guidance has provided support. According to Tammy Whitehouse, author of "Fair-Value Frenzy: Just Document Everything," published in the August 2009 issue of Compliance Week, FSP FAS 157-4 allowed for financial firms' capital ratios to be strengthened as the amendment allowed banks to debit a significant portion of their FV losses to stockholders' equity, as opposed to income (Whitehouse, August 2009, p.28). This move by FASB demonstrates their strong commitment towards restoring orderly markets, and investor confidence.

Finally, with regard to the IASB, prior to October 2008, the organization mandated that financial instruments rendered as "held for sale" be valued at FV under IAS39. As a response to mounting demands and the global financial crisis, the IASB, in October 2008, modified IAS39 to include a provision which allowed financial firms to re-categorize those assets as "held-to-maturity" in special circumstances, such as in the midst of the financial crisis. Held-to-maturity securities are recorded at amortized cost and will only impact the income statement if the asset is impaired and/or if it is prematurely sold (Leone, Nov 14, 2008). However, the IASB was significantly more lenient with its new IAS39 rule as firms could reset the prices of distressed assets back to their July 1, 2008 values if they were considered distressed and eligible (Ibid). Although this "look-back" option may have significantly helped liquidity and solvency ratios for many firms, it certainly appears to present a conservatism issue for U.S. GAAP. Nonetheless, as the International Convergence continues, it is highly doubtful that the FASB and/or the SEC would ever allow for such artistic flexibility with asset values.

\section{ARGUMENTS FOR FV}

Throughout this paper, cases discussing FV's alleged negative ramifications have been presented. Nonetheless, there is a vast array of positive commentary. A summary table of the arguments "for and against FVA" is presented in Exhibit 4. According to an April 2008 report released by Fitch Ratings, the only real issue with FV is that it creates confusion among investors. Firms should only attempt to "improve their disclosures to help investors understand the limitations of estimates" (S. Johnson, April 29, 2008), especially when a market for a particular security has dried up or is non-existent. Yet, in the general marketplace, investors are essentially applauding the use of FV, claiming that the standards, "help them understand the latest and truest worth of a firm's assets and liabilities," since these principles present "realistic and reliable indicators of net present values of a company's future cash flows" (Ibid).

Based on the opinions of the IASB chairman, he predicted "on balance, FV keeps the situation honest" (S. Johnson, March 19, 2008). The IASB indicated that "FV 'seems to be the only measure that is appropriate for all types of financial instruments" (Ibid). Though new accounting pronouncements may have been painful for companies holding financial assets and liabilities to bear at first, this viewpoint illustrates how the implementation of FVA standards can significantly enhance the usefulness of financial statements.

For example, according to FASB's twelve member Investors Technical Advisory Committee (ITAC), blaming FV for facilitating the economic malaise is a "shoot the messenger argument" (Leone, May 30, 2008). The committee argued that the use of FV was a primary factor in the discovery of the "market's widespread problems" (Ibid). Additionally, in the opinion of the group, bank executives who "tried to shift the blame for the current crisis for flawed underwriting, securitization, risk management, and disclosure practices in which they engaged to FV" (Ibid), were unfounded in their assertions. Moreover, the ITAC suggested that the negative arguments were one sided in nature since corporate executives rarely complain when asset values are revalued to a higher hypothetical exit price (Ibid). 
In addition, according to a panel discussing FVA held in 2008, if FV was suspended, the true economic problems would be ignored (Reason, July 9, 2008). For instance, Goldman Sachs' managing director of accounting policy, Matthew Schroeder, claimed that FV was the brokerage firm's "oxygen," and when prices for assets and liabilities were unclear, the company told its traders to "sell small pieces of its holdings "to get a sense of where the market was," in effect, performing "price discovery" (Ibid). Ultimately, argued Schroder, FV should not be viewed as a problem since its alternative is "ignoring the banking industries current woes" (Ibid). In retrospect, based on this assertion, FVA has in fact weeded out the "sour grapes." All markets need checks and balances. Without such, the long-term durability of America's accounting and financial system would be severely impeded.

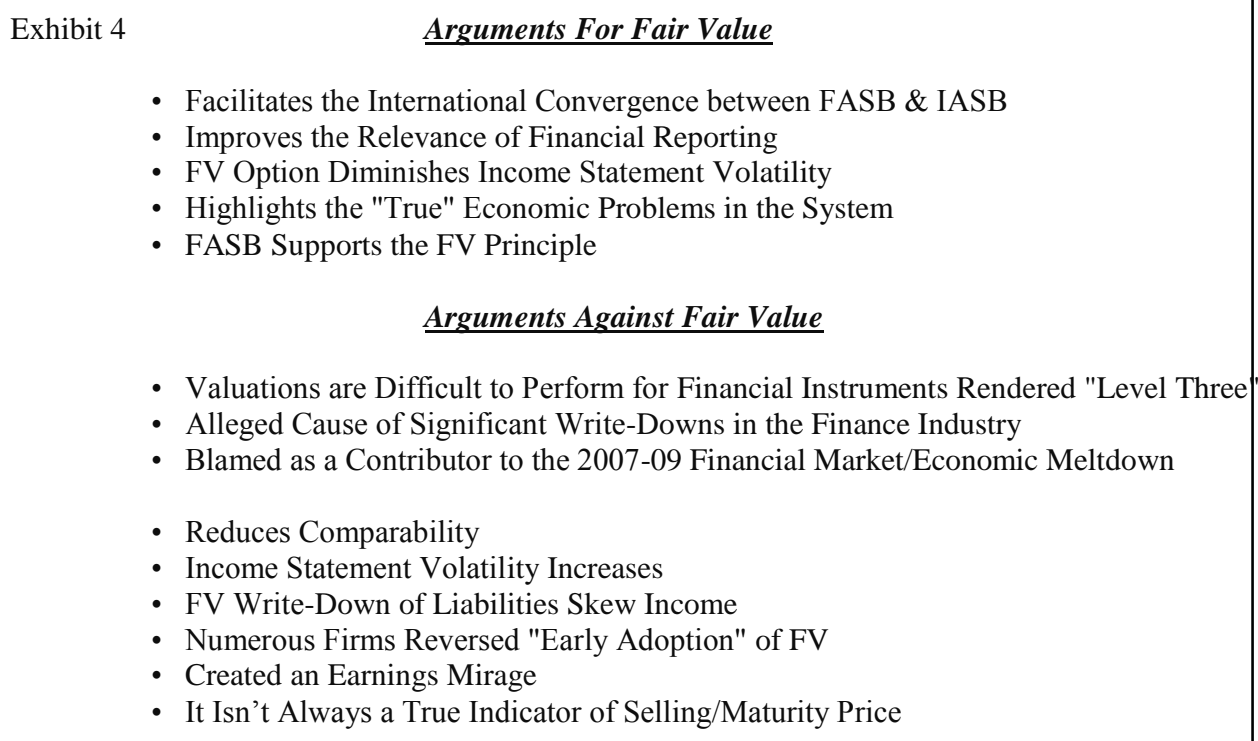

\section{FV GOING FORWARD}

In December 2009, the IASB issued IFRS 9: Financial Instruments, which supersedes IAS39 for financial assets specifically. This new international standard presents a two test rule for financial assets. The first and second tests are called the "business model test" and the "contractual cash flow characteristics" for each instrument, respectively. Under the first test, management would be evaluated as to whether their business planned on purchasing an asset with the intent of selling at a gain or receiving periodic cash flows (Pounder, Dec. 2009, pgs. 19, 20). Assets held for the purpose of selling at a capital gain would need to be measured at their current market values. If the asset is contractual in nature and provides cash flows, it can be carried at its amortized cost only if the cash inflows consist of both "principal and interest" (Pounder, Dec. 2009, p. 20). IFRS 9 models ASC 825-10-25 as it allows for firms to recognize cumulative unrealized gains and losses in equity at the initial application, and the implementation to a particular asset cannot be rescinded. The effective date for this new standard is January 1, 2013, with early adoption encouraged (Pounder, Dec. 2009, p.20). As the international convergence continues, not only is IFRS shaping GAAP, but GAAP is also shaping IFRS.

With regard to the FASB, they are moving forward with FV. For instance, the FASB is expected to issue standards that require all financial instruments to be measured at FV (which will include loans) (Investment Weekly News, Jan. 2010, p. 626). According to Robert Willens, author of "Get Ready for the Next Fair-Value Showdown" in CFO Magazine, however, this new requirement should not be required until at least late-2010. Willens suggested that the banking industry will yet again be opposed to such a measure as they would argue that marking all financial assets and financial liabilities to market would cause "undue earnings volatility" (Willens, August 2009). Essentially, this rule would supersede the FV Option and would require that all financial assets and financial 
liabilities be recorded at FV with changes being reflected either in earnings or other-comprehensive income (Willens, August 2009). This move by the FASB indicates a firm devotion to expanding FV's application in subsequent years.

\section{CONCLUSION}

Overall, FVA appears to be beneficial to financial reporting in many respects. However, there are also major drawbacks. FV measurement is appropriate for level one and level two assets/liabilities, as current market information is readily accessible. The updated valuations are supported by market quotes (level one) or pricing data for similar securities (level two). Thus, any unrealized gains/losses recorded in income can be rendered as a "proper" change, as this market information is "factual" (not based on judgment). Held-to-maturity and available-for-sale securities would typically fall in this category. In this regard, FV should be considered preferable to historical cost as these prices improve financial statement relevance.

On the other hand, level three inputs, which are unobservable in nature, have added significant complexities. Numerous firms did not understand how to appropriately apply ASC820 in inactive markets, and as a result, losses escalated. If the interpretive guidance set forth in FSP FAS 157-4 had been in place initially, it is highly possible that FV would not have been blamed as a catalyst for the financial crisis. In the opinion of the authors, while FV did not cause the bankruptcies of financial services firms, the use of "fire-sale" prices in the financial statements of these beleaguered firms did force capital ratios down to artificially low levels, and consequently, impaired the reliability of the balance sheet and income statement. Accordingly, it can be assumed that the FASB did not anticipate the extreme confusion that would result from these illiquid securities. We question the usefulness of level-three inputs in cases where markets are disorderly. FSP FAS157-4 has alleviated much of this issue going forward, however. Nonetheless, the primary cause of these losses by financial firms is attributed to overly aggressive risk exposure. FVA merely highlighted the financial woes in the sector.

While guidance regarding FV has improved from the initial release of ASC820, there are bound to be many more debates regarding its applicability and usefulness. As the Convergence Project continues, the FASB and the IASB are bound to produce accounting standards that are highly similar. Nonetheless, FV appears likely to be an ever-growing component of U.S. GAAP into the foreseeable future.

\section{AUTHOR INFORMATION}

Karen Cascini has been a professor of Accounting for nineteen years at the John F. Welch College of Business, Sacred Heart University in Fairfield, Connecticut. She teaches advanced accounting courses to undergraduate students and international accounting in the MBA program. Dr. Cascini received her Ph.D. from the University of Connecticut and is a licensed certified public accountant in the state of Connecticut. Her research interests include international and financial accounting and accounting ethics. She has traveled extensively presenting papers and teaching accounting topics to an international audience. She is widely published and her work appears in such journals as the Journal of International Financial Management and Accounting (JIFMA), The CPA Journal, The Journal of Business Case Studies to name a few. Dr. Cascini can be contacted at cascinik@ sacredheart.edu.

Alan DelFavero is currently an adjunct accounting instructor at the John F. Welch College of Business, Sacred Heart University in Fairfield, Connecticut. He teaches introductory financial and managerial accounting courses and intermediate accounting. A Monroe, Connecticut native, in 2006, DelFavero graduated summa cum laude from the Welch College of Business with a finance major and an accounting minor. While immediately pursing his MBA, he worked as Dr. Karen Cascini's graduate research assistant for the academic year 2007/08. DelFavero earned a gold medal, in 2008, for achieving a $3.97 \mathrm{GPA}$, the highest in his graduating class. He is also a member of three national honors societies, and has had other published works appearing in The Journal of Business \& Economics Research and The Journal of Applied Business Research. 


\section{REFERENCES}

1. $\quad$ AIG Press Release. "Second Quarter 2007 Earnings Release.” American International Group. August 8, 2007. Accessed December 8, 2008 from http://media.corporate-ir.net/media_files/irol/76/76115/ reports/Q207_earnings_release.pdf.

2. American Capital Corporation. "2008 Annual Report.” 2009. pgs. 27,57,75,87. Accessed January 6, 2010 from http://phx.corporate-ir.net/External.File?item=UGFyZW50SUQ9MzQ2NjY4fENoaWxkSUQ9MzM

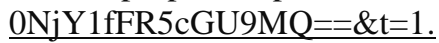

3. Bear Stearns Securities Corporation. "Statement of Financial Condition (Unaudited)" (May 31, 2008). Accessed December 16, 2008 from http://bsscfinancialstatement.com/includes/pdfs/investor_relations/proxy/ bssc_sfc_0508.pdf.

4. $\quad$ Blackstone Group. "2008 Annual Report.” 2009. pg. 14. Accessed January 5, 2010 from http://files.shareholder.com/downloads/BX/812964348x0x292751/3D7B6D30-DD91-4F00-833A5A1B3F96F53E/BX AR08.pdf.

5. Cigna Corporation. “2008 Annual Report.” 2009. pgs. 63, 87. Accessed January 5, 2010 from http://www.cigna.com/about_us/investor_relations/release/10K2008.pdf.

6. Cigna Corporation. "Ann Marie Hagan: Executive Vice President and Chief Financial Officer, CIGNA Corporation, 2010. Accessed January 5, 2010 from http://www.cigna.com/about_us/executives/Hagan.html.

7. CNBC. "Lehman Brothers Files For Bankruptcy, Scrambles to Sell Key Business." September 15, 2008. Accessed January 4, 2010 from http://www.cnbc.com/id/26708143.

8. Deloitte \& Touché LLP Regulatory \& Capital Market Consulting. "Fair Value Adoption: Developments and Observations from the Widespread Adoption of SFAS157 and SFAS159." (August 2008): no 3, p. 12. Accessed January 11, 2010 from http://www.iasplus.com/usa/0808fairvalueupdate.pdf.

9. The Economist. "Finance \& Economics: All's Fair; Accounting." The Economist 388, no. 8598. (Sep 20, 2008). Accessed December 15, 2008, from http://0-

proquest.umi.com.enterprise. sacredheart.edu/pqdweb?index $=0 \&$ did=1557709041\&SrchMode=2\&sid=4\&Fmt=3\&VInst=PROD\&VType=PQD\&RQT =309\&VName=PQD \&TS $=1277607579 \&$ clientId $=15193$

10. Esquivel, Omar \& Gornik-Tomaszewski, Sylwia. "Fair Value Measurements in Impairment Testing: How SFAS No. 157 Increases Consistency and Comparability." Review of Business no 27, 4, (2007): pgs. 20-21.

11. FDIC, "Failed Bank List.” January 2010. Accessed January 4, 2010 from http://www.fdic.gov/bank/individual/failed/banklist.html.

12. Financial Accounting Standards Board. "Memorandum of Understanding: The Norwalk Agreement." Financial Accounting Standards Board. Accessed December 14, 2008 from http://www.fasb.org/news/memorandum.pdf.

13. Financial Accounting Standards Board. "Statement of Financial Accounting Standards No. 107." Financial Accounting Series (December 1991): 4.

14. Financial Accounting Standards Board. "Statement of Financial Accounting Standards No. 119." Financial Accounting Series (October 1994): 4-6.

15. Financial Accounting Standards Board. "Statement of Financial Accounting Standards No. 157." Financial Accounting Series (September 2006): 1, 2, 7, 8, 10-12.

16. Financial Accounting Standards Board. "Statement of Financial Accounting Standards No. 159." Financial Accounting Series (February 2007): 1, 3, 4, 14.

17. Gasparino, Charles. "Bank of America to Buy Merrill Lynch for $\$ 50$ Billion." CNBC Business News. September 14, 2008. Accessed January 5, 2010 from http://www.cnbc.com/id/26708319.

18. Guerrera, Francesco, and Hughes, Jennifer. "AIG Urges Rethink on "Fair Value" Accounting." Financial Times. March 18, 2008. pg. 15.

19. Gramling, Audrey and Hermanson, Dana. "What Do Pending Changes in Accounting and Financial Reporting Mean for Internal Auditors?" Internal Auditing no. 24, 6, (November/December 2009): 36.

20. Henry, Elaine. "Early Adoption of SFAS No. 159: Lessons from Games (Almost) Played." Accounting Horizons no 23, 2, (June 2009): 182, 185, 186, 191, 192.

21. House Committee on Financial Services. "Emergency Economic Stabilization Act of 2008." September 28, 2008. Accessed January 6, 2010 from http://www.house.gov/apps/list/press/financialsvcs_dem/press09 2808.shtml. 
22. Hughes, Jennifer. "Standards-Setter Throws Coals on Hot Fair Value Debate." FT.com. London. (October 11, 2007): 1

23. Imeson, Michael. "Fair Value Accounting Rules Not Fair." The Banker. November 1, 2008. Accessed December 12, 2008 from http://0-proquest.umi.com.enterprise.sacredheart.edu/pqdweb?index $=0 \& \mathrm{did}=1593001881 \&$ SrchMode $=2 \&$ sid $=5 \& \mathrm{Fmt}=3 \& \mathrm{VInst}=\mathrm{PROD} \& \mathrm{VType}=\mathrm{PQD} \& \mathrm{RQT}=309 \& \mathrm{VName}=$ PQD\&TS=1277609949\&clientId=15193

24. Investment Weekly News. "Fitch Ratings; Fitch: Spotlight on the Fair Value of Loans at Major U.S. Banks." January 2, 2010, pg. 626.

25. Johnson, Alex. "Bush Signs Financial Bailout Bill." MSNBC Business. October 3, 2008. Accessed January 6, 2010 from http://www.msnbc.msn.com/id/26987291.

26. Johnson, Carrie. "Wall St. Points to Disclosure as Issue." The Washington Post. September 23, 2008, p D1.

27. Johnson, Sarah. "Cigna Pins 80 Percent Dip on Fair Value." CFO Magazine. May, 12008.

28. Johnson, Sarah. "IFRS: No Longer If, but When" CFO Magazine. February 8, 2008.

29. Johnson, Sarah. "Illiquid Markets Rock Fair-Value Accounting." CFO Magazine. April 29, 2008.

30. Johnson, Sarah. "The Fair-Value Blame Game.” CFO Magazine. March 19, 2008.

31. Johnson, Sarah. "The Global Fair-Value Fight" CFO Magazine. October 6, 2008.

32. Katz, David. 'Fair-Value Accounting's 'Atmosphere of Fear.' CFO Magazine. May 19, 2008.

33. Katz, David, and Reason, Tim. "How Fair Value Rewards Deadbeats." CFO Magazine. July 9, 2008.

34. Krumwiede, Tim, Scadding, Ryan, and Stevens, Craig. "Mortgage-Backed Securities and Fair Value Accounting." CPA Journal. May 2008, pgs. 30-32, 33, 36.

35. Leone, Marie. "Investors Smack Banks for Fair-Value Attack." CFO Magazine. May 30, 2008.

36. Leone, Marie. "Revised Fair Value Rule is Weaker." CFO Magazine. November 14, 2008.

37. Lewis, Michael. "Mass Hysteria Over AIG Obscures Simple Truths." Bloomberg. March 20, 2009.

38. McCarthy, Mark and Schneider, Douglas. "Fair Value Accounting Broadened with FAS159." Commercial Lending Review. (Jul/Aug 2007): p. 28, 32, 34.

39. Pounder, Bruce. “Accounting for Financial Instruments: Post-Crisis Changes, Part 1." Strategic Finance no. 91, 6 (December 2009): 19, 20.

40. Ratcliffe, Thomas. "The Finer Points of Fair Value." Journal of Accountancy no 204, 6: (December 2007): 61.

41. Reason, Timothy. “A Little FV Never Killed Anyone.” CFO Magazine. July 9, 2008.

42. Reason, Timothy. "Why CFOs Hate Fair Value." CFO Magazine. May 14, 2008.

43. Reuters. "AIG Sells \$39.3 Billion in Assets to NY Fed's Fund." CNBC Business News. Accessed December 16, 2008 from http://www.cnbc.com/id/28249308.

44. Securities and Exchange Commission. "Report and Recommendation Pursuant to Section 133 of the Emergency Economic Stabilization Act of 2008: Study on Mark-to-Market Accounting.” (December 2008): pgs. 4,7,8,A-3. Accessed January 6, 2010 from http://www.sec.gov/news/studies/2008/marktomarket123008.pdf.

45. Securities and Exchange Commission. "Mortgage Backed Securities.” June 25, 2007. Accessed January 6, 2010 from http://www.sec.gov/answers/mortgagesecurities.htm.

46. Sinnett, William. "New Fair Value Standards Stress How Not Just What." Financial Executive no 23, 1. (January/February 2007), pg 34.

47. Stein, Robert, and Wesbury, Brian. "Why Mark-to-Market Accounting Rules Must Die.” Forbes.com. February 24, 2009. Accessed June 27, 2010 from http://www.forbes.com/2009/02/23/mark-to-marketopinions-columnists recovery stimulus.html.

48. Taub, Stephen. "FV Rule Triggers \$800 Million Loss.” CFO Magazine. May 8, 2008.

49. Trincal, Emma. "Blackstone Posts Losses Despite Record AUM Growth.” Daily News: White Plains, NY. May 15, 2008.

50. Van Denter, Donald. "Fair Value Accounting, CDOs and the Credit Crisis of 2007-08: Complexity and Model Risk in the Collateralized Debt Obligation Market Are Severe." Bank Accounting \& Finance, 21, no 6, (Oct-Nov 2008), pg. 6.

51. Weiss, Judith. "FSP FAS 157-4: Determining Fair Value When the Volume and Level of Activity for the Asset or Liability Have Significantly Decreased and Identifying Transactions That Are Not Orderly." Miller GAAP Update Service, no. 9, 17, (September 15, 2009). pgs. 1,2.

52. Willens, Robert. "Get Ready for the Next Fair-Value Showdown.” CFO Magazine. August 18, 2009. 
53. Whitehouse, Tammy. "Fair-Value Frenzy: Just Document Everything." Compliance Week, no. 6, 67. (August 2009) p. 28.

54. Yahoo Finance. "AIG: Quarterly Income Statement." Yahoo Finance. Accessed on January 11, 2010 from http://finance.yahoo.com/q/is?s=AIG.

\section{NOTES}

